\title{
Abundance, maturity and growth of the krill species Thysanoessa inermis and T. longicaudata in the Barents Sea
}

\author{
Padmini Dalpadado*, Hein Rune Skjoldal \\ Institute of Marine Research, PO Box 1870 Nordnes, N-5024 Bergen, Norway
}

\begin{abstract}
Thysanoessa inermis and T. longicaudata were the dominant krill species observed in the western and central Barents Sea between 1984 and 1992. Both species are typically boreal and subarctic, and were found in very low abundances in the Arctic water masses in the northern Barents Sea. High abundances (up to 100 to 200 ind $\mathrm{m}^{-2}$ ) of $T$. inermis and $T$. longicaudata were found in the slope and adjoining deep waters south and south east of the Svalbard Bank. The main spawning times of $T$ inermis and T. longicaudata occurred in May-June and coincided with the spring phytoplankton bloom. $T$. inermis has a life span of 3 to 4 yr, while $T$. Iongicaudata can live up to 2 yr. Growth took place from late winter to autumn; a marked negative growth occurred during the late autumn and winter periods. The seasonally oscillating von Bertalanffy growth function gave a reasonably good fit to the growth curves. Coinciding with a strong reduction in the older capelin stock between 1984 and 1987 , there was a subsequent increase in the abundance and biomass of $T$. inermis and $T$ longicaudata. A decrease in krill abundance and biomass was observed to correspond with the rapid recovery and growth of capelin stock up to 1991. This indicates a clear predator-prey interrelationship between planktivorous capelin and krill in the Barents Sea and suggests that the krill populations are to a large extent controlled by predation.
\end{abstract}

KEY WORDS: Krill $\cdot$ Abundance $\cdot$ Growth $\cdot$ Maturity $\cdot$ Predator-prey interactions $\cdot$ Barents Sea

\section{INTRODUCTION}

Previous investigations have shown that a single genus of krill, Thysanoessa, dominates in the Barents Sea. The 2 dominant species in the western Barents Sea are $T$. inermis (Kroyer) and $T$. longicaudata (Krøyer), which are mainly found in the Atlantic waters. They penetrate only to a very limited extent into the Arctic water masses in the northern Barents Sea (Dalpadado \& Skjoldal 1991). T. raschii (M. Sars) is more common in the shallow waters of the eastern Barents Sea (Drobysheva 1987, Timofeev 1988). The larger krill species Meganyctiphanes norvegica (M. Sars) is less common in the Barents Sea and is

·E-mail: padmini@imr.no restricted to the warmer Atlantic water to the west (Einarsson 1945, Lindley 1977, Drobysheva 1979, Dalpadado \& Skjoldal 1991).

Krill form an important part of the diets of many commercially and ecologically important fish species in the Barents Sea, such as capelin, herring, cod, haddock, red fish and polar cod (Lund 1981, Panasenko 1984, Mehl 1989, Ajiad \& Pushchaeva 1991, Skjoldal \& Hassel 1991, Dalpadado 1993). Krill are major prey of planktivorous capelin and can constitute most of the diet of the 13 to $16 \mathrm{~cm}$ size group (Lund 1981. Hassel et al. 1991). The biomass of the 2 yr and older capelin stock decreased drastically from about 2.6 million $t$ in 1983 to 0.7 million $t$ in 1985 and 0.02 million $t$ in 1987 (Gjøsæter 1995). Skjoldal et al. (1992) indicated that after the sharp decline of the capelin stock between 1984 and 1986 there was an increase in large forms of zooplankton such as krill and amphipods and this 
probably again led to high individual growth rate and rapid recovery of the capelin stock up to 1990.

This study is an extension of the work of Dalpadado \& Skjoldal (1991) on the distribution and life history of krill from the Barents Sea. In addition to studying the distribution, growth and life cycles of the 2 dominant krill species Thysanoessa inermis and $T$ longicaudata, we examined the predator-prey interactions between capelin and krill during the study period.

\section{MATERIALS AND METHODS}

The present study is based on samples of krill collected during 18 cruises to the Barents Sea between 1984 and 1992. The sampling area ranged from 73 to $78^{\circ} \mathrm{N}$ and from 10 to $45^{\circ} \mathrm{E}$. Some of the data on krill from 1984 to 1989 (from 6 cruises) are extracted from Dalpadado \& Skjoldal (1991).

The samples, obtained from MOCNESS (Wiebe et al. 1985) with a $1 \mathrm{~m}^{2}$ mouth opening, were used to determine the abundances and size distributions of krill. Samples were preserved in $4 \%$ formalin. Sub-samples were obtained using a Motoda plankton splitter. Krill were identified to species, and the number in each sample or sub-sample was recorded. The carapace length $(C L$, from the base of the eye-stalk to the posterior lateral edge of the carapace) was measured and rounded down to the nearest $\mathrm{mm}$ (Mauchline 1980). For Thysanoessa raschii and Meganyctiphanes norvegica, total length ( $\mathrm{TL}$, from tip of the rostrum to tip of telson) was recorded in addition to carapace length because the catches of these 2 species were too low to obtain any reliable relationship between carapace and total lengths. For $T$ inermis and $T$ longicaudata, $\mathrm{CL}$ was converted to $\mathrm{TL}$ with the following regression equations:

For $T$. inermis

$$
\begin{gathered}
\mathrm{CL}=0.352 \mathrm{TL}-1.092 \\
\left(\mathrm{n}=166, \mathrm{TL} \text { range }=9 \text { to } 29 \mathrm{~mm}, \mathrm{r}^{2}=0.92\right)
\end{gathered}
$$

(from Dalpadado \& Skjoldal 1991)

For T. longicaudata:

$$
\begin{gathered}
\mathrm{CL}=0.261 \mathrm{TL}-0.198 \\
\left(\mathrm{n}=303, \mathrm{TL} \text { range }=6 \text { to } 15 \mathrm{~mm}, \mathrm{r}^{2}=0.856\right)
\end{gathered}
$$

The regressions given below describe the relationships between TL and dry body weight (DW). These regressions and information on mean lengths were used to convert data on numerical abundance to biomass.

For $T$. inermis:

$$
\begin{gathered}
\log W W=3.33 \log T L-2.58 \\
D W=0.335 W W-1.256\left(n=19, r^{2}=0.994\right)
\end{gathered}
$$

For T longicaudata:

$$
\begin{gathered}
\mathrm{DW}=0.7 \mathrm{TL}-5.8 \\
\left(\mathrm{n}=18, \mathrm{TL} \text { range }=10 \text { to } 21 \mathrm{~mm}, \mathrm{r}^{2}=0.96\right)
\end{gathered}
$$

The data on abundance (ind. $\mathrm{m}^{-2}$ ), biomass $\left(\mathrm{mg} \mathrm{m}^{-2}\right.$ ) and density (ind $\mathrm{m}^{-3}$ ) of krill estimated in a MOCNESS profile were classified into data from Arctic, Atlantic and Polar Front regions using the descriptions of water masses given by Loeng $(1989,1991)$

Length frequency histograms for pooled data from each cruise were resolved into normally distributed components (cohorts) using Bhattacharya's analysis as implemented in the LFSA (length frequency sample analysis) by Sparre (1987). The mean lengths of the separated year classes were then used to obtain the seasonal growth pattern over the life span of the krill. The allocation of cohorts (year classes) was done according to the methods of Dalpadado \& Skjoldal (1991). Growth equations were fitted to the von Bertalanffy growth function (VBGF) modified for seasonal oscillations (Somers 1988) using the Macintosh version of the SYSTAT module NONLIN.

\section{RESULTS}

\section{Geographical distribution}

The horizontal distributions of the 2 dominant krill species Thysanoessa inermis and $T$ longicaudata are shown in Figs. $1 \& 2$ as the average abundances within ca $30 \times 30$ nautical mile grids during the study period, between 1984 and 1992. Table 1 shows the mean abundances and biomasses of these 2 species in Atlantic/Polar Front and Arctic water masses for each separate cruise

The major characteristic of Thysanoessa inermis and $T$. Jongicaudata distributions is that they are mainly restricted to the Atlantic and subarctic waters. Very low abundances (usually below 5 ind. $\mathrm{m}^{-2}$ ) were recorded in the Arctic water The areas of distribution for $T$. inermis and $T$. longicaudata overlap to a large extent, although the abundance and biomass of $T$ inermis were in general higher. The highest abundances and biomasses of $T$. inermis (up to 207 ind. $\mathrm{m}^{-2}$ and $3000 \mathrm{mg} \mathrm{m}^{-2}$, respectively) and $T$ longicaudata (up to 100 ind. $\mathrm{m}^{-2}$ and $169 \mathrm{mg} \mathrm{m}^{-2}$ ) were observed in the deeper waters south and southeast of the Svalbard Bank. The highest abundances and biomasses of these species were observed in 1988 and 1989.

Meganyctiphanes norvegica, a warmer water species, was present only in the southwestern Barents Sea. The highest abundances of $M$. norvegica were recorded at 2 stations sampled in March and October 
1988 at $73^{\circ} 30^{\prime} \mathrm{N}, 19^{\circ} 20^{\prime} \mathrm{E}$ and $73^{\circ} 30^{\prime} \mathrm{N}, 19^{\circ}$ $50^{\prime} \mathrm{E}$ (47.5 and 11.6 ind. $\mathrm{m}^{-2}$, respectively). The abundance of $M$. norvegica was otherwise quite low (mean $=0.37$ ind $\mathrm{m}^{-2}$ ). Thysanoessa raschii was recorded on most cruises, but with low abundance (mean $=1.08$ ind. $\mathrm{m}^{-2}$, range $=0.012$ to 3.80 ind $\mathrm{m}^{-2}$ ).

Fig 3 shows the numerical densities of Thysanoessa inermis and $T$ longicaudata plotted against depth in vertical profiles at the sampling stations for 3 different time periods: January-March, May-August and September-October. The krill seemed to be distributed throughout the water column at all time periods, although densities above 4 ind. $\mathrm{m}^{-3}$ were found only in deeper areas at depths between 400 and $500 \mathrm{~m}$.

\section{Growth and life span}

Length frequency distributions for Thysanoessa inermis and $T$ longicaudata from Atlantic and Polar Front regions were resolved into normal distribution components using Bhattacharya's analysis. Statistical splitting of length frequency distributions usually gave 3 or 4 cohorts for $T$ inermis and 1 or 2 for $T$ longicaudata. $T$ inermis mean lengths were: 0 -group $=10.45 \mathrm{~mm}$ $($ range $=8.2$ to $12.8 \mathrm{~mm}) ; 1-$ group $=13.9 \mathrm{~mm}($ range $=$

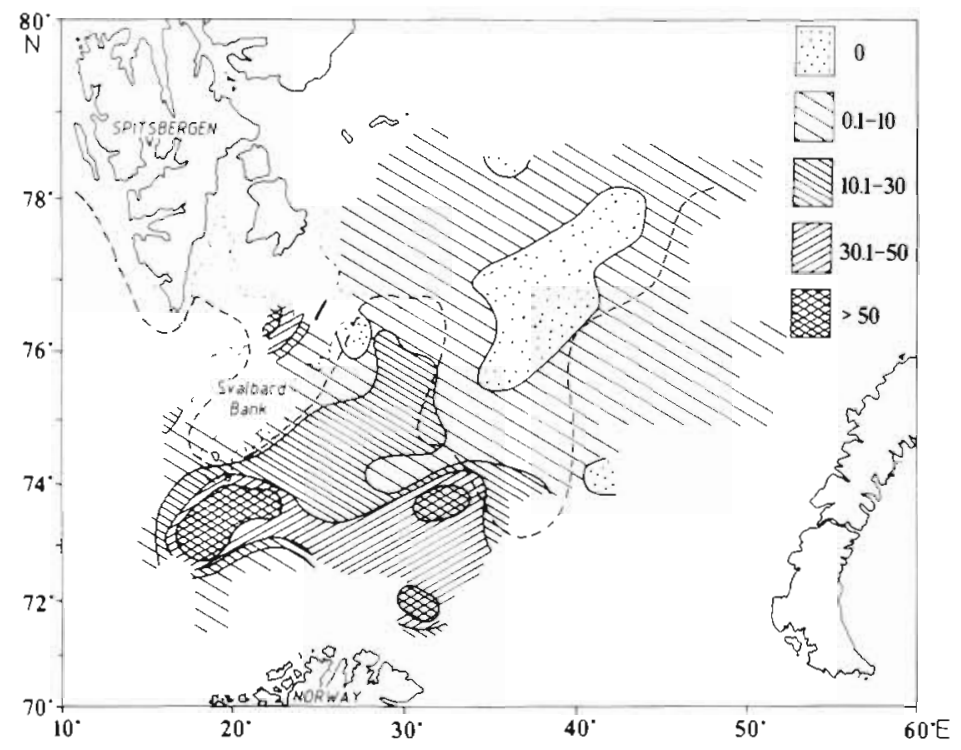

Fig. 1 Thysanoessa inermis. Horizontal distribution in the Barents Sea, based on average numerical abundance (ind. $\mathrm{m}^{-2}$ ) from all cruises 1984-1992. (--) Polar Front. Note that samples were not obtained outside the shaded areas, and the figure therefore does not show the total distribution area in the Barents Sea

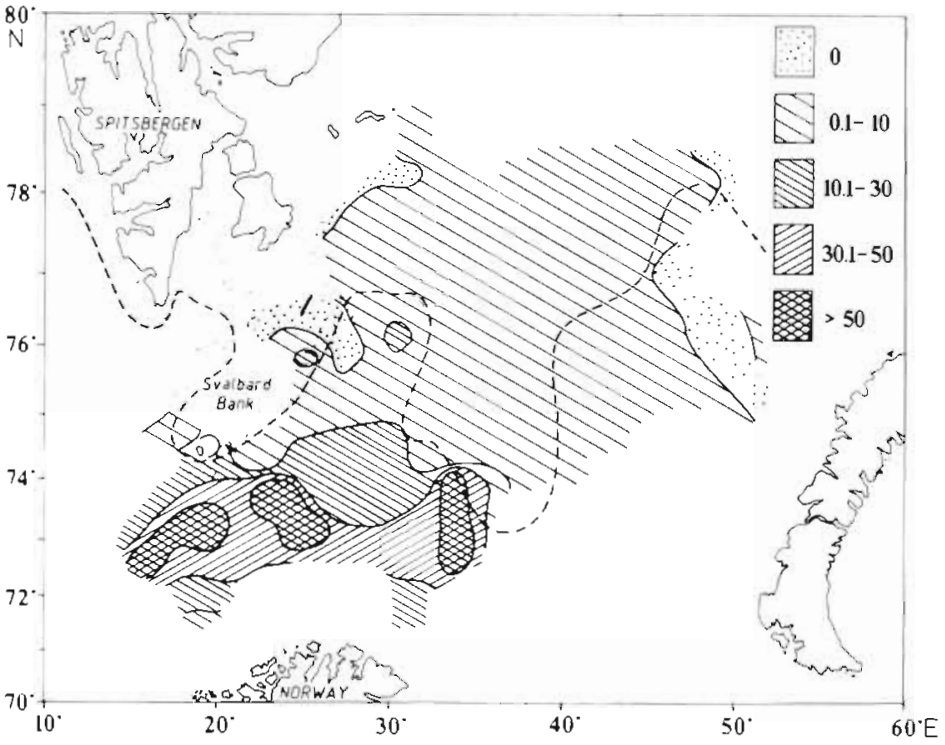

Fig. 2. Thysanoessa longicaudata. Horizontal distribution in the Barents Sea, based on average numerical abundance (ind. $\mathrm{m}^{-2}$ ) from all cruises, 1984-1992. (--) Polar Front. Note that samples were not obtained outside the shaded areas, and the figure therefore does not show the total distribution area in the Barents Sea

11.6 to $18.7 \mathrm{~mm}) ; 2$-group $=18.5 \mathrm{~mm}($ range $=15.6$ to $21 \mathrm{~mm})$; and $3-$ group $=22.7 \mathrm{~mm}$ (19.7 to $25.6 \mathrm{~mm}$ ). For $T$. longucaudata, the mean length was $9.3 \mathrm{~mm}$ (range $=$ 8.0 to $11.1 \mathrm{~mm}$ ) for the first mode and $12.8 \mathrm{~mm}$ (range $=10.7$ to $15.1 \mathrm{~mm}$ for the second mode. On 2 occasions (cruises in September-October 1992 and August 1985), a third cohort (mean $=17.2 \mathrm{~mm}$, range $=15.8$ to $18.5 \mathrm{~mm}$ ) with a few individuals was observed.

The seasonal variations in mean length of cohorts of Thysanoessa inermis and T. longicaudata are shown in Fig 4 The main growth of $T$. inermis seemed to occur from about February to August, whereas for $T$. longicaudata the growth period extended until October. A marked negative growth was apparent in $T$. inermis from August to February. A clear negative growth was seen also for $T$ longicaudata in January.

The seasonalized version of VBGF was fitted to the growth data. The resulting growth curves are shown in. Fig. 5 and the parameter values are given in Table 2 . The seasonalized version gave reasonably good fits (corrected $r^{2}$ $=0.92$ for $T$. inermis and 0.85 for Thysanoessa longicaudata). The $t_{\mathrm{s}}$ values (see Table 2) were quite similar for the 2 species whereas the amplitude of the growth oscillations $(C)$ was much higher for $T$. inermis $(C=2.8)$ than for $T$ longicaudata $(C=1.5)$. 
Table 1 Thysanoessa inermis and T longicaudata. Means and ranges of numerical abundance (ind. $\mathrm{m}^{-2}$ ), length (mm) and biomass ( $\mathrm{mg} \mathrm{m}^{-2}$ ) observed during different cruises between 1984 and $1992 \mathrm{in}$ Atlantic/Polar Front and Arctic water masses

\begin{tabular}{|c|c|c|c|c|c|c|c|}
\hline \multirow[t]{2}{*}{ Cruise } & \multirow[t]{2}{*}{ No. of stations } & \multicolumn{2}{|c|}{ Abundance (1nd. $\mathrm{m}^{-2}$ ) } & \multicolumn{2}{|c|}{ Length (mm) } & \multicolumn{2}{|c|}{ Biomass ( $\mathrm{mg} \mathrm{m}^{-2}$ ) } \\
\hline & & Mean & Range & Mean & Range & Mean & Range \\
\hline \multicolumn{8}{|c|}{ Atlantic/Polar Front } \\
\hline \multicolumn{8}{|l|}{ T. inermis } \\
\hline Jun 1984 & 6 & 2.8 & $0.0-9.2$ & ca 18 & & 33.6 & $0.0-111.5$ \\
\hline Jan 1985 & 7 & 23.1 & $0.9-62.5$ & 12.9 & $8.0-25.0$ & 71.6 & $3.9-231.3$ \\
\hline Aug 1985 & 8 & 1.9 & $0.0-7.5$ & 15.9 & $8.0-27.0$ & 26.6 & $0.0-124.8$ \\
\hline Apr 1986 & 4 & 10.8 & $2.8-25.1$ & 13.1 & $8.0-25.0$ & 37.0 & $7.7-76.8$ \\
\hline May 1986 & 2 & 7.7 & $1.5-13.9$ & 14.6 & $10.0-22.0$ & 46.8 & $6.8-86.7$ \\
\hline Jan-Mar 1987 & 6 & 36.0 & $6.8-114.5$ & 12.0 & $8.0-25.0$ & 168.1 & $6.9-819.9$ \\
\hline May-Jun 1987 & 9 & 16.6 & $1.5-60.3$ & 16.8 & $8.5-27.0$ & 152.2 & $12.8-432.3$ \\
\hline March 1988 & 6 & 59.1 & $3.4-207.2$ & 14.9 & $8.0-25.8$ & 620.2 & $9.1-2769.6$ \\
\hline Oct 1988 & 5 & 32.8 & $0.0-152.3$ & 14.0 & $8.0-29.0$ & 569.9 & $0.0-2812.1$ \\
\hline Jan 1989 & 6 & 60.8 & $33.5-130.0$ & 16.7 & $7.0-30.0$ & 583.0 & $266.1-1279.0$ \\
\hline May 1989 & 3 & 45.8 & $8.0-117.8$ & 17.5 & $11.0-27.0$ & 1088.0 & $33.5-3134.2$ \\
\hline Sep-Oct 1990 & 3 & 10.5 & $5.4-13.1$ & 12.2 & $8.2-22.7$ & 42.7 & $0.6-105.9$ \\
\hline Jan-Feb 1991 & 3 & 37.7 & $14.3-72.4$ & 12.6 & $7.9-29.2$ & 114.2 & $33.4-228.7$ \\
\hline May-Jun 1991 & 6 & 2.4 & $0.0-3.89$ & 19.3 & $13.9-27.0$ & 38.1 & $0.0-60.3$ \\
\hline Sep-Oct 1992 & 6 & 34.9 & $3.8-80.8$ & 11.9 & $7.1-29.5$ & 84.4 & $1.2-182.6$ \\
\hline Sep-Oct 1992 & 5 & 8.6 & $1.0-35.9$ & 13.5 & $9.1-21.6$ & 33.2 & $0.6-132.6$ \\
\hline \multicolumn{8}{|l|}{$T$ longicaudata } \\
\hline Jun 1984 & 6 & 1.9 & $0.0-4.5$ & ca 10 & & 2.2 & $0.0-5.4$ \\
\hline Jan 1985 & 7 & 4.1 & $0.0-14.4$ & 11.4 & $6.5-15.0$ & 8.9 & $0.0-29.4$ \\
\hline Aug 1985 & 8 & 2.5 & $0.0-8.5$ & 9.9 & $6.0-16.0$ & 1.2 & $0.0-3.1$ \\
\hline Apr 1986 & 4 & 1.6 & $0.6-3.4$ & 11.8 & $8.0-16.0$ & 3.8 & $1.8-8.8$ \\
\hline May 1986 & 2 & 2.5 & $0.7-4.4$ & 11.4 & $9.0-14.0$ & 5.6 & $1.6-9.6$ \\
\hline Jan-Mar 1987 & 6 & 18.9 & $3.7-56.1$ & 9.4 & $6.0-14.0$ & 12.7 & $2.4-35.8$ \\
\hline May-Jun 1987 & 9 & 27.4 & $3.2-13.1$ & 10.6 & $7.3-16.2$ & 51.2 & $3.4-170.3$ \\
\hline March 1988 & 6 & 42.3 & $3.5-1.00 .2$ & 9.2 & $4.0-15.0$ & 44.2 & $0.06-113.3$ \\
\hline Oct 1988 & 5 & 26.9 & $6.6-61.6$ & 9.7 & $5.0-16.0$ & 38.2 & $2.8 \quad 168.7$ \\
\hline Jan 1989 & 6 & 45.0 & $9.4-63.6$ & 10.0 & $5.5-17.0$ & 51.3 & $16.5 \quad 77.4$ \\
\hline May 1989 & 3 & 36.4 & $12.6-79.9$ & 10.7 & $8.0-15.5$ & 59.5 & $19.5-123.8$ \\
\hline Sep-Oct 1990 & 3 & 9.4 & $0.6-15.7$ & 13.3 & $8.8-18.0$ & 33.2 & $1.9-56.4$ \\
\hline Jan-Feb 1991 & 3 & 12.8 & $7.7-17.2$ & 9.9 & $6.1-15.3$ & 14.1 & $7.1-22.9$ \\
\hline May-Jun 1991 & 6 & 3.9 & $1.0-7.08$ & 12.4 & $9.5-16.5$ & 11.8 & $2.9-21.4$ \\
\hline Sep-Oct 1992 & 6 & 11.4 & $0.0-33.7$ & 11.3 & $5.3-18.8$ & 11.5 & $0.1-26.7$ \\
\hline Sep-Oct 1992 & 5 & 12.6 & $0.0-61.0$ & 11.9 & $6.1-18.0$ & 22.1 & $0.0-88.1$ \\
\hline \multicolumn{8}{|l|}{ Arctic } \\
\hline \multicolumn{8}{|l|}{$T$ inermis } \\
\hline Aug 1984 & 21 & 0.3 & $0.0-3.7$ & 18.7 & $13.0-22.8$ & 3.5 & $0.0-26.8$ \\
\hline Aug 1985 & 11 & 0.5 & $0.1-1.5$ & 20.0 & $13.0-26.0$ & 8.0 & $0.0-19.4$ \\
\hline Sep 1988 & 3 & 0.3 & $0.0-0.9$ & 21.0 & $17.0-25.0$ & 6.2 & $0.0-18.6$ \\
\hline Sep-Oct 1990 & 3 & 0.7 & $0.0-2.0$ & 14.8 & $13.0-17.0$ & 3.8 & $0.0-11.4$ \\
\hline Sep-Oct 1992 & 5 & 2.0 & $0.0-6.7$ & 17.7 & $6.2-28.4$ & 17.8 & $0.8-49.2$ \\
\hline Sep-Oct 1992 & 5 & 0.7 & $0.0-2.5$ & 12.7 & $10.5-14.9$ & 1.6 & $0.0-5.8$ \\
\hline \multicolumn{8}{|l|}{ T longicaudata } \\
\hline Aug 1984 & 21 & 0.4 & $0.0-2.6$ & 13.6 & $5.5-16.2$ & 1.7 & $0.0-10.9$ \\
\hline Aug 1985 & 11 & 1.1 & $0.0-5.3$ & 12.6 & $6.5-17.0$ & 2.8 & $0.0-20.4$ \\
\hline Sep 1988 & 3 & 1.5 & $0.6-2.4$ & 14.5 & $11.0-17.0$ & 6.2 & $3.4-10.9$ \\
\hline Sep-Oct 1990 & 3 & 1.5 & $0.0-4.1$ & 13.7 & $12.0-19.9$ & 8.1 & $0.0-23.6$ \\
\hline Sep-Oct 1992 & 5 & 1.9 & $0.0-5.0$ & 14.8 & $8.8-19.9$ & 7.3 & $0.0-19.8$ \\
\hline Sep-Oct 1992 & 5 & 0.5 & $0.0-1.3$ & 14.2 & $8.0-15.0$ & 37.8 & $0.0-114.7$ \\
\hline
\end{tabular}

\section{Krill abundance, biomass and growth in relation to capelin stock size}

The mean biomasses of Thysanoessa inermis and $T$. longicaudata observed in each year from 1984 to 1992 and the stock size of capelin 2 yr and older recorded from 1982 to 1993 are shown in Fig. 6. The capelin stock collapsed from 1984 to very low levels in 1986. There was a subsequent strong increase in the abundances and biomasses of both krill species (Table 1 , Fig. 6) with an earlier increase for $T$. longicaudata, which has the shortest life span. The capelin stock 


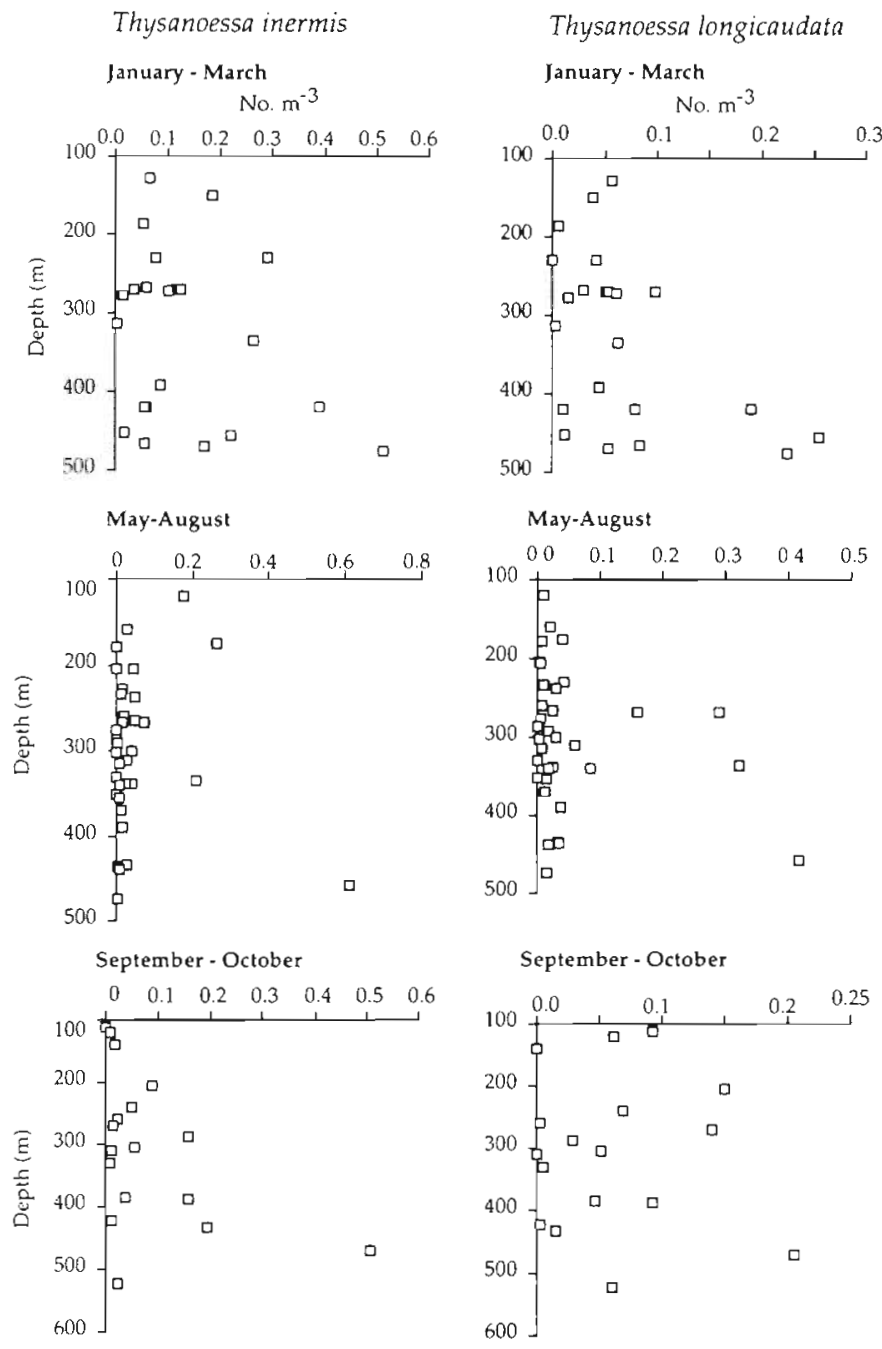

Fig. 3. Thysanoessa inermis and $T$ longicaudata. Numerical density (ind $\mathrm{m}^{-3}$ ) in relation to depth in vertical profiles at sampling stations in Atlantic/Polar Front water masses

recovered rapidly after 1989 to a very high level in 1991 At the same time, there was a marked decrease in abundances and biomasses of the krill species, most pronounced for $T$ inermis.

Length and age frequency distributions for Thysanoessa inermis and $T$. longicaudata are presented in Figs. $7 \& 8$, respectively, and in Table 3 , for 3 time periods: 1984 to 1986, when capelin stock size was decreasing; 1987 to 1989 , when the stock was at low levels; and 1990 to 1992, when the stock was high. During 1987 to 1989 , when the capelin stock was very low, the larger (>20 mm) and old age groups (2 and $3 \mathrm{yr}$ ) of $T$. inermis were present, probably due to reduced grazing pressure from capelin (Fig. 7, Table 3). During periods with anticipated heavy predation by capelin a higher proportion of smaller individuals was observed and only $20 \%$ of the individuals were in age

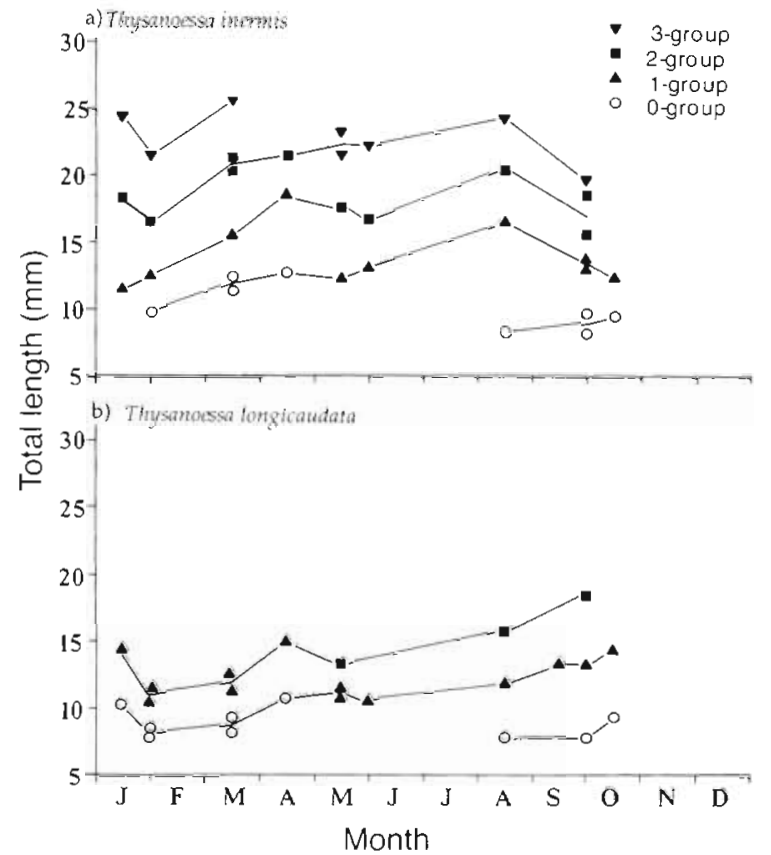

Fig. 4. (a) Thysanoessa inermis and (b) $T$ longicaudata. Seasonal variation in mean length of individual cohorts separated by length frequency analysis. The identified cohorts have been ascribed to age groups

Table 2. Thysanoessa inermis and $T$ longicaudata. Parameters of von Bertalanffy growth function (VBGF) with seasonal oscillations: $L_{\infty}=$ asymptotic length; $K=$ growth constant; $t_{\mathrm{s}}=$ starting point of oscillation with respect to time $t, t_{0}=$ origin of the growth curve; $1 C$ =amplitude of growth oscillation

\begin{tabular}{ccc|}
\hline Parameter & T.inermis & T. longicaudata \\
\hline$r^{2}$ & 0.93 & 0.85 \\
$L_{\infty}$ & 45.00 & 20.11 \\
$\mathrm{~K}$ & 0.16 & 0.56 \\
$t_{\mathrm{s}}$ & 0.88 & 1.09 \\
$t_{0}$ & -0.41 & -0.27 \\
$\mathrm{C}$ & 2.80 & 1.47 \\
\hline
\end{tabular}

groups 2 and 3 compared to $59 \%$ during 1987 to 1989 , a period with low predation. The mean length and age of $T$. longicaudata did not vary much during the different periods.

\section{DISCUSSION}

In the current study, the amount of krill caught at night was usually higher than in the daytime, especially in autumn (September-October) and in spring (March-April) cruises. Our investigations also show that the krill catches in summer were somewhat lower than in winter. Krill abundance might have been underestimated in the current study, although the 

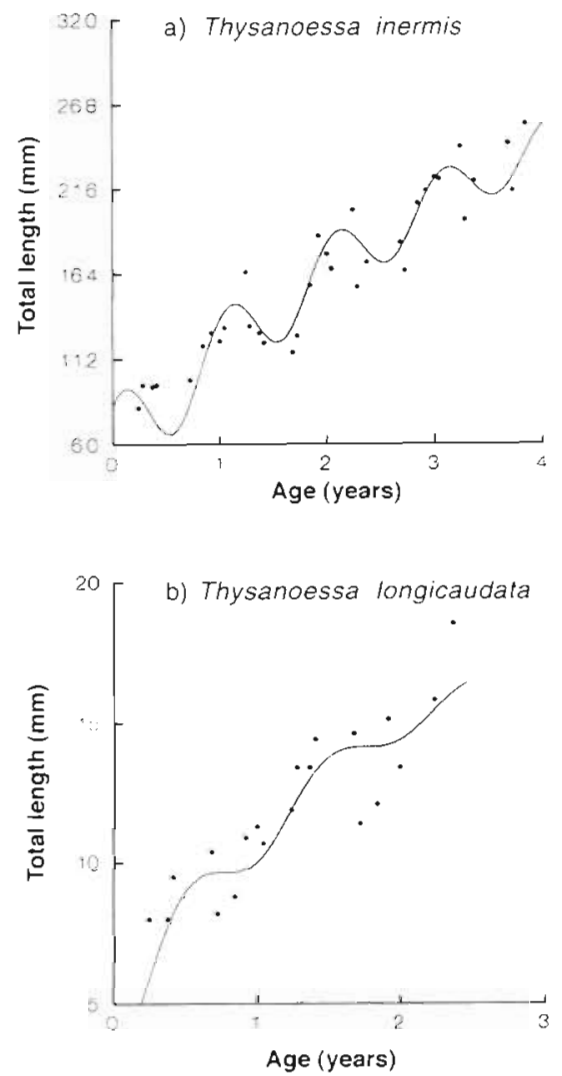

Fig. 5. (a) Thysanoessa inermis and (b) $T$ longicaudata. Growth data fitted with seasonalized version of von Bertalanffy growth curve

Table 3. Thysanoessa inermis, $T$ longicandata. Age distribution of krill (\%) for the months January to August in the years 1984 to 1986 and January to October in the years 1987 to 1989 and 1990 to 1992

\begin{tabular}{|lccc|}
\hline & & \multicolumn{3}{c|}{ Age group } \\
& & 0 and 1 & 2 and 3 \\
\hline T. inermis & $1984-1986$ & 80.4 & 19.6 \\
& $1987-1989$ & 41.3 & 58.7 \\
& $1990-1992$ & 79.5 & 205 \\
T. Longicaudata & $1984-1986$ & 63.1 & 36.9 \\
& $1987-1989$ & 100.0 & \\
& $1990-1992$ & 100.0 & \\
& & & \\
\hline
\end{tabular}

extent of this is not clear. In a previous paper (Dalpadado \& Skjoldal 1991), we discussed some possible factors (visual avoidance of nets, towing speed and sampling range of MOCNESS) that could lead to underestimates of krill abundance.

Our observations on the geographical distribution of krill confirm earlier studies (Einarsson 1945, Dunbar 1964, Mauchline 1980, Dalpadado \& Skjoldal 1991) which reported that none of the krill species found in. the Barents Sea are true Arctic species.
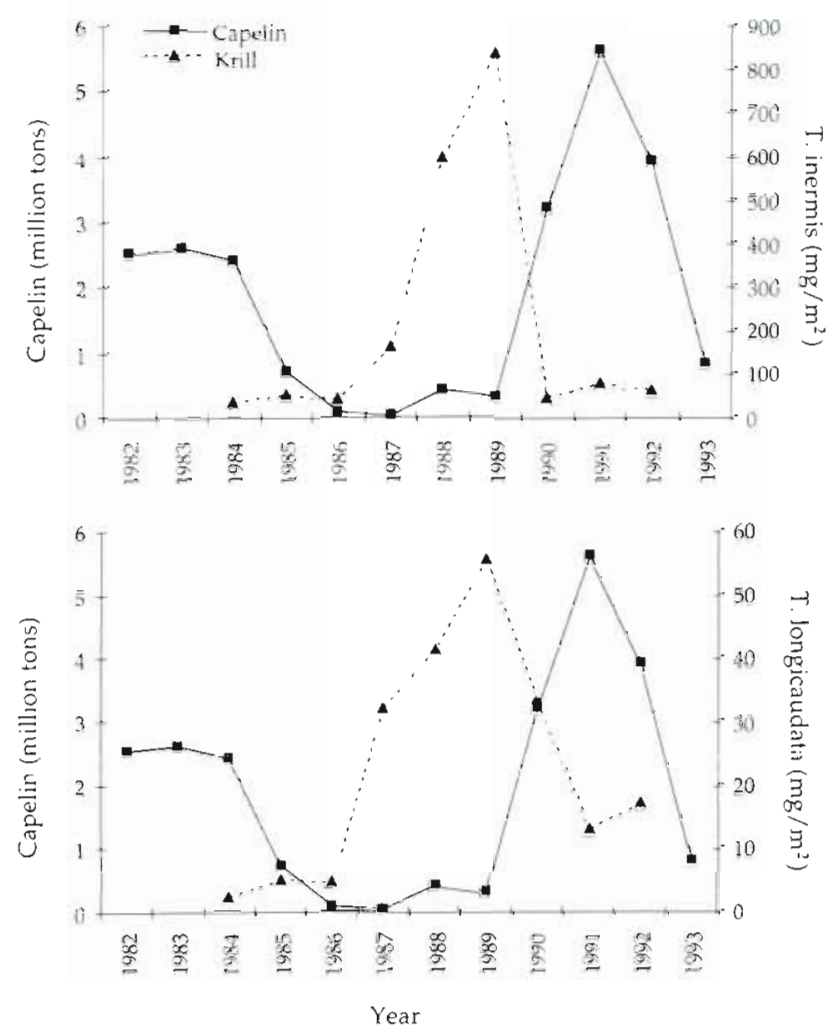

Fig. 6. Thysanoessa inermis and T. longlcaudata. Variation in biomass (mg dry wt $\mathrm{m}^{-2}$ ) of krill from 1984 to 1992 and the stock size of $2 y$ r and older capeln (million t) from 1982 to 1993

Thysanoissa inermis and $T$ longicaudata were the most abundant krill species found in the investigated area ( 73 to $78^{\circ} \mathrm{N}$ and 10 to $45^{\circ} \mathrm{E}$ ) covering Atlantic, Polar Front (region of mixed Arctic and Atlantic water) and Arctic waters. The largest of these 2 species, $T$. inermis (up to $35 \mathrm{~mm}$ ), was the most abundant. The highest abundances ( 11.5 to 207 ind. $\mathrm{m}^{-2}$ ) and densities 10.25 to 0.60 ind $\mathrm{m}^{-3}$ ) of this species were found in the slope and deep waters ( 300 to $500 \mathrm{~m}$ ) south and southeast of the Svalbard Bank. High concentrations, up to 2 ind $\mathrm{m}^{-3}$, of $T$ inermis have also been reported from the shallower areas around the Svalbard. Bank (Drobysheva 1979. Drobysheva \& Panasenko 1984, Timofeev 1988).

Thysanoessa longicaudata was found at most stations where $T$ inermis was present, although at lower abundances. For $T$. longicaudata, the highest abundances were recorded from the southwestern part of the Barents Sea ( 72 to $74^{\circ} \mathrm{N}, 15$ to $20^{\circ} \mathrm{E}$ ), indicating that this species is more closely associated with Atlantic water than is $T$ inermis. Drobysheva (1979) made similar observations on this species in the Barents Sea. Abundances of $T$ inermis and $T$. longicaudata were generally higher in winter (January-March) than in other seasons. 
Thysanoessa inermis
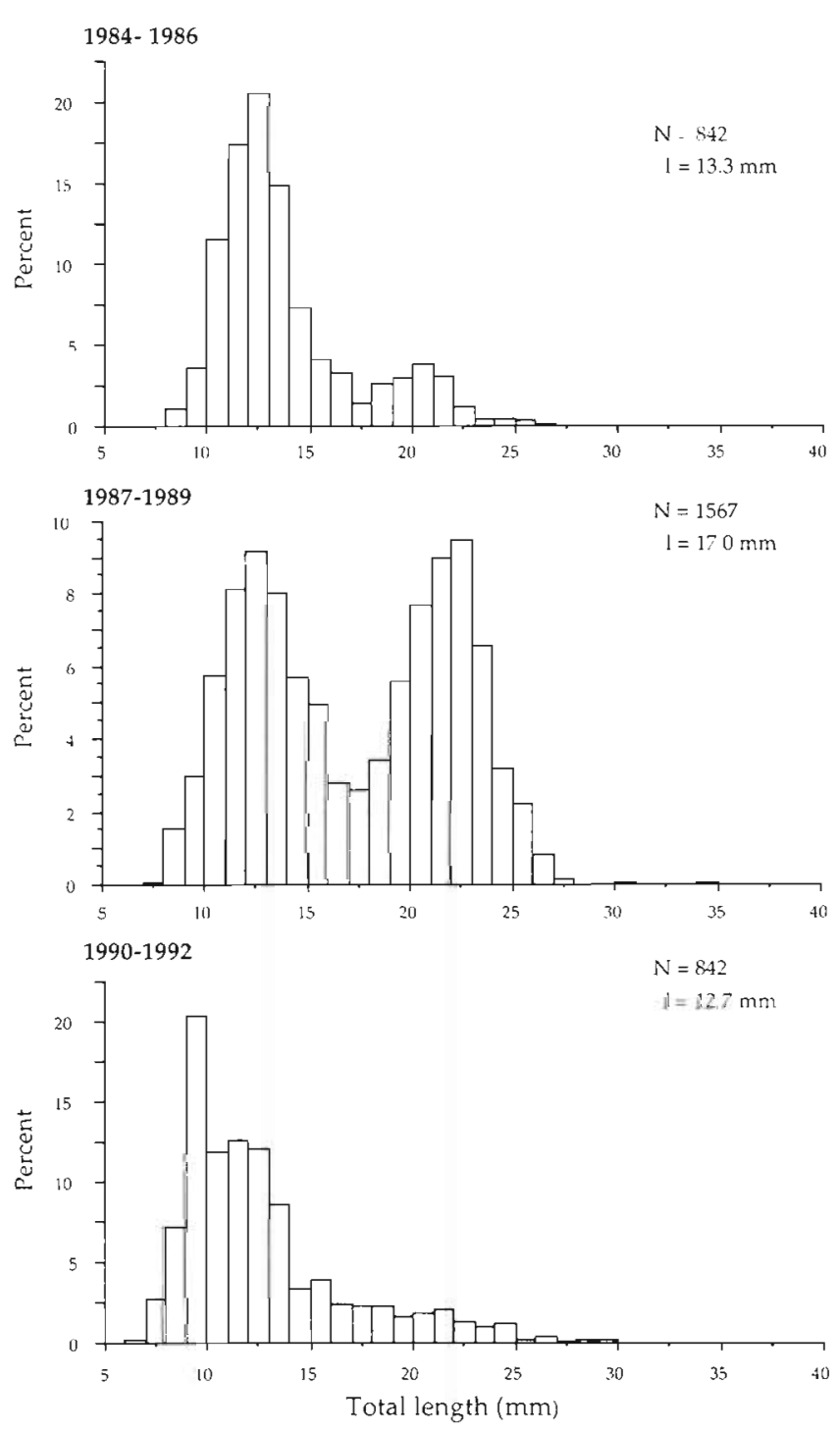

Fig. 7. Thysanoessa inermis. Length-frequency histograms for different time periods. $N=$ number of $k$ rill, $1=$ mean length

The study of Lofnes (1993) on the distributions of krill eggs and larvae from the western and central Barents Sea supports our observations on the distributions of adult krill. He found the highest abundances of eggs and larvae of Thysanoessa inermis (mean $=12500$ ind. $\mathrm{m}^{-2}$ ) and $T$. longicaudata ( mean $=1050$ ind. $\mathrm{m}^{-2}$ ) in the Atlantic water in May 1989; in the Polar Front region, the mean abundances were lower than in the Atlantic waters (4702 and 188 ind. $\mathrm{m}^{-2}$, respectively). Only eggs and larvae of $T$. inermis (mean 520 ind $\mathrm{m}^{-2}$ ) were found in Arctic waters. His observations showed very low abundances of eggs and larvae of $T$. raschii and Meganyctiphanes norvegica in the studied area.
Thysanoessa longicaudata
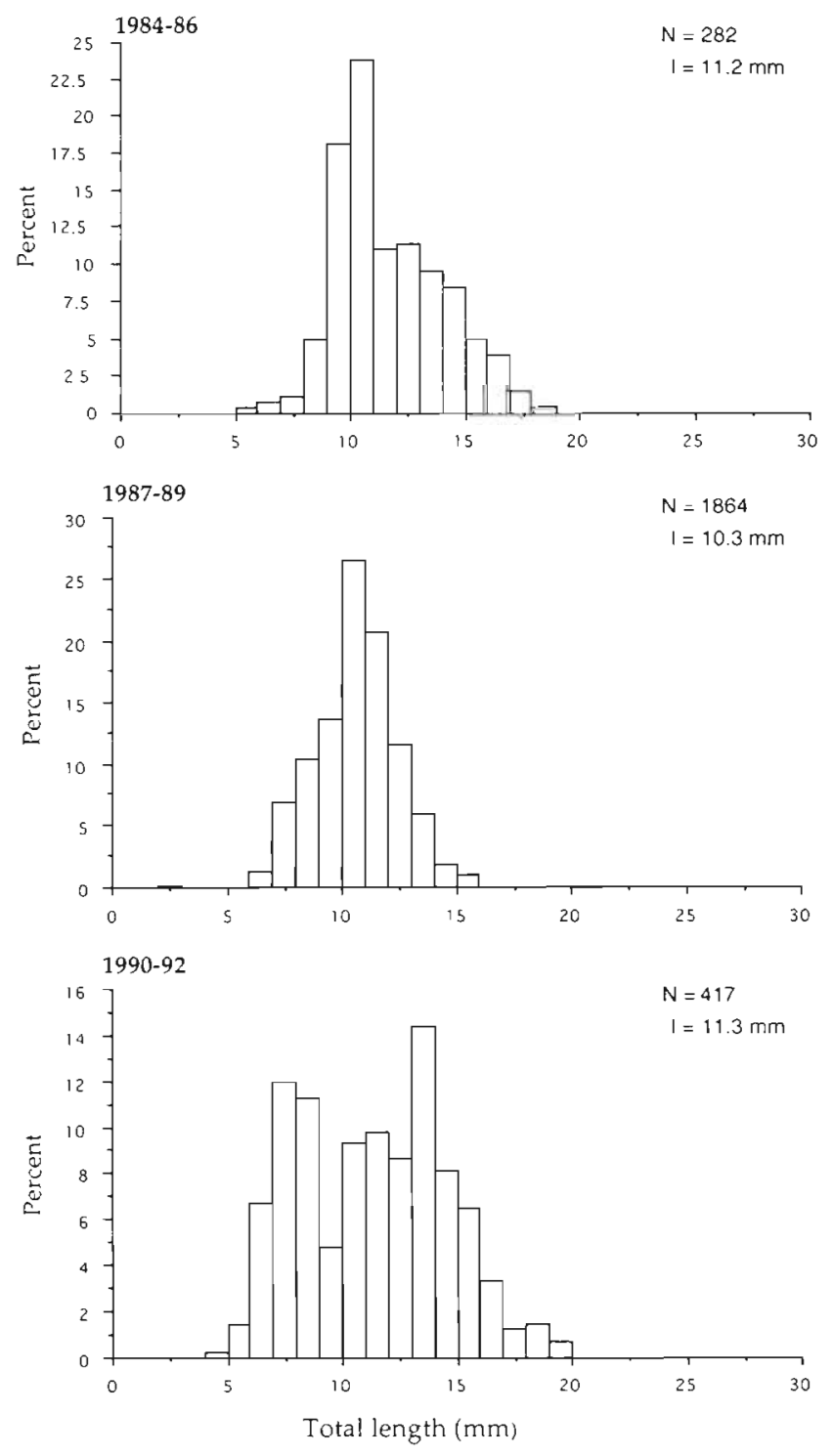

Fig. 8. Thysanoessa longicaudata. Length-frequency histograms for different time periods. $N=$ number of $\mathrm{krill}, \mathrm{l}=$ mean length

Dalpadado \& Skjoldal (1991) showed that both Thysanoessa inermis and $T$. longicaudata reproduce successfully in the Barents Sea and that the reproductive cycles of these 2 species were very similar. Their study and that of Zelikman (1958) showed that the main spawning season of these 2 species in the Barents Sea is from May to June. Maturity observations from the present study confirm these findings. The spawning of $T$ inermis and $T$ longicaudata seemed to coincide well with the main phytoplankton bloom in May-June (Skjoldal \& Rey 1989, Dalpadado \& Skjoldal 1991). The study of Astthorsson (1990) showed that the spawning of $T$ inermis and $T$. raschii in the Isafjord- 
deep, northwest Iceland, occurred during the spring phytoplankton bloom development.

As the main spawning season of Thysanoessa inermis and $T$ longicaudata is restricted to May and June. we assume that each length cohort represents a year class with a denoted change of age in spring. Our results indicate a 3 to 4 yr life span for $T$. inermis and a 2 yr lifesapan for $T$. longicaudata, with maturation and first spawning occurring at the age of $2 \mathrm{yr}$ and $1 \mathrm{yr}$, respectively, for the 2 species (Dalpadado \& Skjoldal 1991). Einarsson (1945) reported that $T$. inermis could live for $3 \mathrm{yr}$ in western Greenland waters. In more southerly waters, $T$. inermis has a life cycle of 1 to $2 \mathrm{yr}$ (Einarsson 1945, Jørgensen \& Matthews 1975, Kulka \& Corey 1978, Astthorsson 1990).

The main growth of Thysanoessa inermis in terms of length seems to occur from February to August. FalkPetersen \& Hopkins (1981) made a similar observation for $T$. inermis from a fjord (Balsfjorden) in northern Norway. T. longicaudata seems to have a more extended growth period than $T$. inermis, from February to October A marked negative growth was apparent for $T$. inermis as early as August. During mid winter (January-February) a clear decrease in growth was seen for 2-and 3-group $T$. inermis as well as for 1 - and 2 -group $T$. longicaudata. Negative growth during winter when food supply is low is reported in other studies (Falk-Petersen \& Hopkins 1981. Hopkins et al. 1984, Astthorsson 1990). Laboratory experiments on both Antarctic and Atlantic/Arctic krill have shown that negative growth is common, with positive growth being an exception under experimental conditions (Ikeda \& Dixon 1982, Polek \& Denys 1982, Dalpadado \& Ikeda 1989, Buchholz 1991). As Dalpadado \& Skjoldal (1991) pointed out, decrease in size might not pose many problems for population dynamic studies based on length-frequency distributions for short-lived species with well-defined spawning seasons such as $T$. inermis and $T$ longicaudata.

For Thysanoessa inermis, a clear increase in size was seen between 1987 and 1989. When predation was minimal, reduced mortality allowed more individuals to grow into older age groups. The mean lengths of $T$. longicaudata were similar during periods with high and low predation activity by capelin. This could be because more cruises (e.g. August 1984, 1985 and September-October 1992) covered the colder waters where larger individuals of $T$. longicaudata were recorded. $T$ longicaudata is apparently more dependent on the inflow from the Norwegian Sea than is T. inermis, which is more a shelf species. Major inflow events took place in 1982-1983 and 1989 and reduced inflow in 1987-1988 (Loeng 1991, Adlandsvik \& Loeng 1991). It is possible that the inflow events transported a smaller proportion of $T$ longicaudata into the colder regions of the Barents Sea where they grow to a larger size and older age. $T$. inermis from different water masses did not show marked variation in size.

The capelin stock spends its whole life in the Barents Sea, spawning along the southern coast and feeding in the central and northern parts (Gjosæter 1995). The krill distribution area overlaps with the feeding grounds of capelin, especially in the winter to early summer period. Krill are important food for capelin in the Barents Sea (Lund 1981, Ajiad \& Pushchaeva 1991, Hassel et al. 1991, Skjoldal \& Hassel 1991). Lund (1981) showed that the amount of krill consumed by capelin (13 to $16 \mathrm{~cm}$ length) in terms of calories could vary from 28 to $98 \%$ of the diet during different seasons. The highest values were observed in spring and the lowest in autumn.

The biomass of capelin $2 \mathrm{yr}$ and older decreased drastically from about 2.6 million $t$ in 1983 to 0.7 million $\mathrm{t}$ by 1985 (Fig. 6). In 1984, there was a low biomass of zooplankton in the Barents Sea and the individual growth of capelin was low (Skjoldal et al. 1992). By 1987, the biomass of capelin was down to 0.02 million $t$ (Gjøsæter 1995). The reduction in the capelin stock in the mid 1980s most likely eased the grazing pressure on krill and this probably led to the increase in abundance of Thysanoessa inermis and $T$ longicaudata. The strong decrease in krill abundance as the capelin stock size increased was probably caused by increased predation from capelin. The high abundance of large zooplankton prey, such as krill, probably contributed to the high growth rate and rapid recovery of the capelin stock (Skjoldal et al. 1992). Skjoldal et al (1992) further suggested that the abundance of krill is regulated by predation to a large extent. Dalpadado et al. (1994) found similar trends in the variation of abundance of amphipods (Themisto spp.) between 1984 and 1992. These results therefore indicate clear predatorprey interactions between capelin and their major prey, such as krill and amphipods, in the Barents Sea

Acknowledgements. Thus project was partially financed by the Norwegian Ministry of Industry and Energy as part of the AKUP project on consequences of petroleum activities in the Barents Sea. We thank Signe Johannessen for analyzing the krill samples.

\section{LITERATURE CITELD}

Adlandsvik B, Loeng H (1991) A Study of the climatic system in the Barents Sea. In: Sakshaug E, Hopkins CCE, Øritsland NA (eds) Proceedings of the Pro Mare Symposium on Polar Marine Ecology, Trondheim, Norway, 12-16 May 1990. Polar Res 10:45-49

Ajiad AM, Pushchaeva T (1991) The daily feeding dynamics in various length groups of the Barents Sea capelin. In: Bogstad B, Tjelmeland S (eds) Interrelations between fish 
populations in the Barents Sea. Proceeedings of the 5 th PINRO/IMR Symposium, Murmansk, 12-16 August 1991 p 181-192

Astthorsson OS (1990) Thysanoessa raschii, T. inermis and Meganytiphanes norvegica in Isafjord-deep, northwest Iceland. Mar Biol 107:147-157

Buchholz F (1991) Moult cycle and growth of Antarctic krill Euphausia superba in the laboratory: Mar Ecol Prog Ser 69:217-229

Dalpadado P (1993) Some observations on the feeding ecology of Norwegian sprnng spawning herring Clupea harengus along the coast of Norway. C.M.-ICES/L 47:1-11

Dalpadado P. Borkner N, Skjoldal HR (1994) Distribution and life history of Themisto (Amphipoda) spp., north of $73^{\circ} \mathrm{N}$ in the Barents Sca. Fisken Havet 12:1-42

Dalpadado P. Ikeda T (1989) Some observations on moultıng, growth and maturation of krill (Thysanoessa inermis) from the Barents Sea. J Plankton Res 11:133-139

Dalpadado P, Skjoldal HR (1991) Distribution and life history of krill from the Barents Sea. In: Sakshaug E, Hopkins $\mathrm{CCE}_{\text {, }} \varnothing$ ritsland NA (eds) Proceedings of the Pro Mare Symposium on Polar Marine Ecology, Trondheim, Norway, 12-16 May 1990. Polar Res 10:443-460

Drobysheva SS (1979) Distribution of the Barents Sea euphausiids (fam. Euphausiacea). C.M.-ICES L8:1-18

Drobysheva SS (1987) Population characteristics of abundant Barents Sea Euphausiacea. C.M.-ICES L12:1-15

Drobysheva SS, Panasenko LD (1984) On consumption of the Barents Sea euphausiids. C.M.-ICES L7:1-12

Dunbar MJ (1964) Serial atlas of the marine environment. Folio 6. Euphausiids and pelagic amphipods. American Geographical Society, New York, p 1-2

Einarsson H (1945) Euphausiacea 1 Northern Atlantic species. Dana-Rep Carlsberg Found 27:1-185

Falk-Petersen S, Hopkins CCE (1981) Ecological investıgations of the zooplankton community of Balsfjorden, northern Norway: population dynamics of the euphausidds Thysanoessa inermis (Kroyer). Thysanoessa raschii (M Sars) and Meganytiphanes norvegica (M. Sars) in 1976 and 1977. J Plankton Res 3:177-192

Gjøsæter H (1995) Pelagic fish and the ecological impact of modern fishing industry in the Barents Sea. Arctic 48 $267-278$

Hassel A, Skjoldal HR, Gjøsceter H, Loeng H, Omli L (1991.) Impact of grazing from capelin (Mallotus villosus) on zooplankton: a case study in the northern Barents Sea in August 1985. In: Sakshaug E, Hopkins CCE, Øritsland NA (eds) Proceedings of the Pro Mare Symposium on Polar Marine Ecology, Trondheim, Norway, 12-16 May 1990 Polar Res 10:371-388

Hopkins CCE. Tande KS, Gronvik S, Sargent JR (1984) Ecological investigations of the zooplankton community of Balsfjorden, northern Norway. An analysis of growth and overwintering tactics in relation to niche and environment in Metridia longa (Lubbock), Calanus finmarchicus (Gunnerus). Thysanoessa inermis (Krøyer) and $T$ raschii (M Sars). J Exp Mar Biol Ecol 82:77-99

Ikeda T, Dixon P (1982) Body shrinkage as a possible overwintering mechanism of the Antarctic krill Euphausia superba Dana. J Exp Mar Biol Ecol 62:143-151

Jorgensen G, Matthews JBL (1975) Ecological studies on the deep water pelagıc community of Korsfjorden, western

This article was submitted to the editor
Norway. Population dynamics of six species of exphausiids in 1968 and 1969. Sarsia 59:67-84

Kulka DW. Corey S (1978) The life history of Thysanoessa inermis (Kroyer) in the Bay of Fundy. Can J Zool 56 : 492-506

Lindley JA (1977) Continuous plankton records: the distribution of the Euphausiacea (Crustaced: Malacostraca) in the north Atlantic and the North Sed, 1966-1967 I Biogeogr $4: 121-133$

Loeng H (1989) Ecological features of the Barents Sea. In: Rey L, Alexander V (eds) Proceedings of the 6 th Conference of the Comite Arctique Internat 13-15 May 1985. EJ Brill, Now York, p 327-365

Loeng $\mathrm{H}$ (1991) Features of the physical oceanographic conditions of the Barents Sea. In: Sakshaug E, Hopkins CCE, Oritsland NA (eds) Proceedings of the Pro Mare Symposium on Polar Marine Ecology, Trondheim, Norway, 12-16 May 1990. Polar Res 10:5-18

Lofnes SP (1993) Reproduction of krill in the Barents Sea. Distribution and length studies of eggs and larvae of krill in July 1988 and May 1989 related to water masses and algae biomass. CSc thesis, University of Bergen

Lund A (1981) Feeding ecology of capelin Mallotus villosus (Müller) in the Barents Sea. CSc thesis, University of Bergen

Mauchline J (1980) The biology of mysids and euphausiids. In: Blaxter JHS, Russell FS, Yonge $M$ (eds) Advances in manne biology. Academic Press, London, 18:1-681

Mehl S (1989) The northeast Arctic cod stock's consumption of commercially exploited prey species in 1984-1986. Rapp PV Réun Cons Int Explor Mer 188:185-205

Panasenko LG (1984) Feeding of the Barents Sea capelin. C.M.-ICES H 6:1-6

Polek TP, Denys CJ (1982) Effect of temperature on the moulting, growth and maturation of the Antarctic krill Euphausia superba (Crustacea: Euphausiacea) under laboratory conditions. Mar Biol 70:255-265

Skjoldal JR, Gjosæeter H, Loeng H (1992) The Barents Sea ecosystem in the 1980s: ocean climate, plankton, and capelin growth. ICES Mar Sci Symp 195:278-290

Skjoldal HR, Hassel A (1991) Feeding conditions of capelin and herring in the Barents Sea. Institute of Marine Research Rep No. 1/1991/HSM, Bergen, Norway, p 1-25

Skjoldal HR, Rey F (1989) Pelagic production and variability of the Barents Sea ecosystem. In: Sherman K, Alexander LM (eds) Biomass yields and geography of large marine ecosystems. American Association for the Advancement of Science. Selected Symposium 11. Westview Press, Boulder, CO, p 241-286

Somers I (1988) On a seasonally oscillating growth function. Fishbyte 6:8-11

Sparre P (1987) Cumputer programs for fish stock assessment. FAO Fish Tech Pap, Rome, 101:1-218

Timofeev SF (1988) Abundance of euphausiids at the coast of eastern Murmansk in winter. Sov J Mar Biol 13:174-177

Wiebe PH, Morton AW, Bradley AM, Backus RH, Craddock JE, Barber V, Cowles TJ, Flierl GR (1985) New developments in the MOCNESS, an apparatus for sampling zooplankton and micronekton. Mar Biol 87:313-323

Zelikman EA (1958) On gonad maturation and female productivity in species of euphausians abundant in the Barents Sea. Dokl Akad Nauk SSSR 11:201-204

Manuscript first received: November 20, 1995

Revised version accepted: July 18, 1996 